\title{
Mannose Corrects Altered N-Glycosylation in Carbohydrate-deficient Glycoprotein Syndrome Fibroblasts
}

\author{
K. Panneerselvam and Hudson $\mathbf{H}$. Freeze \\ La Jolla Cancer Research Foundation, La Jolla, California 92037
}

\begin{abstract}
Type I carbohydrate-deficient glycoprotein syndrome (CDGS) patients fail to add entire $\mathrm{N}$-linked oligosaccharide chains to some serum glycoproteins. Here we show that four CDGS fibroblast cell lines have two related glycosylation abnormalities. First, they incorporate $3-10$-fold less $\left[{ }^{3} \mathrm{H}\right]$ mannose into proteins, and, second, the size of the lipid-linked oligosaccharide precursor (LLO) is much smaller than in controls. Addition of exogenous mannose, but not glucose, to these CDGS cells corrects both the lowered $\left[{ }^{3} \mathrm{H}\right]$ mannose incorporation and the size of LLO. These corrections are not permanent, and the defects immediately reappear when mannose is removed. To explore further the basis of mannose correction, we analyzed the amount of ${ }^{3} \mathrm{H}$-labeled LLO intermediates. Except for dolichol-P-mannose, other precursors, including mannose, mannose-6-phosphate, mannose-1-phosphate, and GDP-mannose, all showed a 3-10fold decrease in CDGS cells. Thus, there are no obvious lesions in the intracellular conversion of mannose into LLO, and, once inside the cell, $\left[{ }^{3} \mathrm{H}\right]$ mannose appeared to be metabolized normally. Initial velocities of $\left[{ }^{3} \mathbf{H}\right]$ mannose uptake were two- to threefold less in CDGS cells compared with controls, and this slower transport may partially explain the reduced $\left[{ }^{3} \mathrm{H}\right]$ mannose incorporation in CDGS cells. Since we previously showed that the enzymes converting glucose to mannose-6-phosphate appear to be normal, our results suggest that cells may acquire or generate mannose in other ways. Although we have not identified the primary defect in CDGS, these studies show that intracellular mannose is limited and that some patients might benefit from including mannose in their regular diets. (J. Clin. Invest. 1996. 97:1478-1487.) Key words: glycosylation • lipidlinked oligosaccharide - glycoprotein $\bullet$ hexose transporter • CDG syndrome
\end{abstract}

\section{Introduction}

Carbohydrate-deficient glycoprotein syndromes (CDGS) ${ }^{1}$ are autosomal recessive disorders that affect multiple organ systems $(1,2)$. All patients show altered isoelectric focusing patterns of multiple serum glycoproteins that result from undersialylation of their N-linked oligosaccharides $(3,4)$. The

Address correspondence to Hudson H. Freeze, La Jolla Cancer Research Foundation, 10901 N. Torrey Pines Rd., La Jolla, CA 92037. Phone: 619-455-6480; FAX: 619-450-2101.

Received for publication 10 November 1995 and accepted in revised form 5 January 1996.

J. Clin. Invest.

(C) The American Society for Clinical Investigation, Inc. 0021-9738/96/03/1478/10 \$2.00

Volume 97, Number 6, March 1996, 1478-1487 reduced sialylation in one patient with the rarer type II CDGS can be fully explained by the absence of Golgi enzyme GlcNAc transferase II $(1,5)$. This enzyme is required to make sialylated biantennary $\mathrm{N}$-linked oligosaccharides typical of many serum glycoproteins (6). The undersialylation in the more common type I CDGS clearly results from the complete absence of one or more $\mathrm{N}$-linked oligosaccharide chains on the proteins (7-10). The basis of this defect has been proposed to be in the biosynthesis of the lipid-linked oligosaccharide (LLO) precursor or its transfer to proteins $(1,7,8)$. However, CDGS fibroblasts appear to be normal in oligosaccharyl transferase and in UDP-GlcNAc:dolichol phosphate GlcNAc-1-P transferase, the first enzyme in LLO biosynthesis $(11,12)$.

We recently reported that the carbohydrate content of total serum glycoproteins from two CDGS patients was reduced by $\sim 30 \%$, but the monosaccharide composition and types of $\mathrm{N}$-linked oligosaccharides were normal (13). Metabolic labeling of two fibroblasts with $\left[{ }^{3} \mathrm{H}\right]$ mannose showed a $2.5-5$-fold decrease in the incorporation into both glycoproteins and LLO of CDGS cells compared with controls. We have now expanded this study to four CDGS patients and found that reduced protein glycosylation probably results from an inadequate supply of mannose needed for $\mathrm{N}$-linked oligosaccharide biosynthesis, and not from a clear lesion in any step leading to protein glycosylation. Adding exogenous mannose to cells in culture corrects the biochemical lesions.

\section{Methods}

Materials. Most of the materials were obtained from Sigma Chemical Co. (St. Louis, MO), except for the following: concanavalin A (Con A)-Sepharose (Pharmacia Fine Chemicals, Piscataway, NJ), $\alpha$-MEM (GIBCO BRL, Baltimore, MD), FBS (Hyclone Laboratories, Logan, UT), Micropak AX-5 HPLC column (Varian Instruments, Walnut Creek, CA), and microspin filters (Lida Manufacturing Corp., Kenosha, WI).

Radiolabels. 2- $\left[{ }^{3} \mathrm{H}\right]$ Mannose $(15 \mathrm{Ci} / \mathrm{mmol}), 2-\operatorname{deoxy}\left[1,2-{ }^{3} \mathrm{H}(\mathrm{N})\right]-$ glucose $(40 \mathrm{Ci} / \mathrm{mmol})$, and $\left[{ }^{35} \mathrm{~S}\right]$ methionine $(1,217 \mathrm{Ci} / \mathrm{mmol})$ were obtained from American Radiolabeled Chemicals, Inc. (St. Louis, MO).

Cell lines. The CDGS and control cell lines were all obtained from Dr. Neil Buist (Department of Pediatrics, Oregon Health Sciences University, Portland, OR). CDGS 1 and 2, our designation, are patients from the same family (samples F27467 and F27468) described in our previous study (13). CDGS cell lines 3 and 4 are patients from another family (samples F20660 and F02661, coded by Dr. N. Buist). All these patients are diagnosed as type I CDGS based on the clinical and biochemical (transferrin pattern) analyses. Disease

1. Abbreviations used in this paper: $\alpha$-MeMan, $\alpha$-methyl mannoside; CDGS, carbohydrate-deficient glycoprotein syndrome; Con A, concanavalin A; dol-P-Man, dolichol-P-mannose; Endo H, endoglycosidase H; GDP-Fuc, GDP-fucose; GDP-Man, GDP-mannose; LLO, lipid-linked oligosaccharide; Man, mannose; Man-1-P, mannose-1phosphate; Man-6-P, mannose-6-phosphate; PMI, phosphomannose isomerase. 
control fibroblasts are from pediatric patients with lactic acidosis, fatty acid/glutaric disorders, and movement disorders, expressing normal transferrin patterns. Normal adult fibroblasts (CRL 1826) were obtained from American Type Culture Collection (Rockville, MD).

Cell lines were grown in $\alpha$-MEM containing $10 \%$ heat-inactivated FBS and $2 \mathrm{mM}$ glutamine. When the long-term effect of mannose was studied, both normal and CDGS cells were grown for $10 \mathrm{~d}$ in the regular growth medium containing $1 \mathrm{mM}$ D-mannose, and the medium was changed every day.

Determination of incorporation of $\left[{ }^{3} \mathrm{H}\right]$ mannose. Fibroblasts in 35$\mathrm{mm}$ multiwell plates were labeled with $\left[{ }^{3} \mathrm{H}\right]$ mannose $(20 \mu \mathrm{Ci} / \mathrm{ml})$ and $\left[{ }^{35} \mathrm{~S}\right]$ methionine $(2 \mu \mathrm{Ci} / \mathrm{ml})$ for $60 \mathrm{~min}$ in DMEM containing $0.5 \mathrm{mM}$ glucose and $2 \mathrm{mM}$ glutamine. After removal of the radioactive medium, cells were quickly washed three times with ice-cold PBS and harvested by trypsinization, counted, sonicated, and solubilized in $0.1 \%$ SDS. The lysate was divided into four aliquots and used for protein determination and TCA precipitation before and after peptide: $\mathrm{N}$-glycosidase F (PNGase F) or endoglycosidase H (Endo $\mathrm{H}$ ) digestion. TCA-precipitated radiolabel was counted and normalized to protein content. PNGase $\mathrm{F}$ and Endo $\mathrm{H}$ digestions were done as described previously (14).

Isolation and characterization of $\left[{ }^{3} \mathrm{H}\right]$ mannose-labeled products from cellular fraction. Fibroblasts grown in glass plates were labeled for $30 \mathrm{~min}$ with $\left[{ }^{3} \mathrm{H}\right]$ mannose $(100 \mu \mathrm{Ci} / \mathrm{ml})$ in DMEM containing 0.5 $\mathrm{mM}$ glucose and $2 \mathrm{mM}$ glutamine (15). After removing the labeling medium, cells were quickly washed three times with ice-cold PBS to remove free label, and the plate was immediately flooded directly with $5 \mathrm{ml}$ of chloroform/methanol $\left(\mathrm{CHCl}_{3} / \mathrm{MeOH}, 2: 1 \mathrm{vol} / \mathrm{vol}\right)$ at $0^{\circ} \mathrm{C}$ (15). Cells were scraped and stored at $-20^{\circ} \mathrm{C}$ until processed. Cells were vortexed to disperse cell clumps and centrifuged at 3,000 rpm for $5 \mathrm{~min}$. Pellets were extracted twice with $5 \mathrm{ml}$ of the same solvent, and this combined extract (fraction I) was used to measure dolicholP-mannose (dol-P-Man) content. The residual pellet after $\mathrm{CHCl}_{3} /$ $\mathrm{MeOH}$ extraction was dried under a stream of nitrogen, suspended in $1 \mathrm{ml}$ of water, sonicated, centrifuged, and washed three times with $5 \mathrm{ml}$ of water. This combined water wash (fraction II) was used to measure labeled free oligosaccharides, mannose phosphates, and sugar nucleotides. The remaining cell pellet was extracted three times with $5 \mathrm{ml}$ of $\mathrm{CHCl}_{3} / \mathrm{MeOH} / \mathrm{H}_{2} \mathrm{O}(10: 10: 3 \mathrm{vol} / \mathrm{vol})$ (fraction III) to isolate LLO. Oligosaccharides from the lipid were released by mild acid hydrolysis (15). The final cell pellet was solubilized in $0.1 \%$ SDS (fraction IV) and digested with PNGase F to release the proteinbound N-linked oligosaccharides (14), which were reduced with sodium borohydride in sodium borate buffer, $\mathrm{pH} 9.8$, desalted, and analyzed by HPLC on an amine adsorption column with a linear gradient of acetonitrile (65-35\%) in water as described previously (16).

Measurement of dol-P-Man. $\mathrm{CHCl}_{3} / \mathrm{MeOH}$ extract (fraction I) was partitioned into $\mathrm{CHCl}_{3} / \mathrm{MeOH} / \mathrm{H}_{2} \mathrm{O}(3: 2: 1 \mathrm{vol} / \mathrm{vol})$. The organic phase was dried, hydrolyzed in $0.01 \mathrm{~N} \mathrm{HCl}$ for $15 \mathrm{~min}$ at $100^{\circ} \mathrm{C}$, and again partitioned into $\mathrm{CHCl}_{3} / \mathrm{MeOH} / \mathrm{H}_{2} \mathrm{O}$ (3:2:1 vol/vol). Radioactivity partitioning into the aqueous phase was taken as dol-P-Man content (17). Authentic dol-P-Man was completely hydrolyzed under these conditions and partitioned into the aqueous phase. The quantitation of labeled dol-P-Man by this method was confirmed by thinlayer chromatography and by counting individual $0.5-\mathrm{cm}$ sections.

Separation of water soluble components on Con A-Sepharose. The water-soluble material in fraction II was fractionated on Con A-Sepharose in microfuge spin filter baskets as described below. Material that did not bind to Con A was used for estimating the amount of mannose phosphates and sugar nucleotides. Con A-bound material was eluted with $100 \mathrm{mM} \alpha$-methyl mannoside ( $\alpha$-MeMan) and applied to a G-10 Sephadex column to remove $\alpha$-MeMan. The single radioactive peak near the void volume (Vo) was pooled, concentrated, and loaded on to QAE-Sephadex (in spin columns). The unbound neutral oligosaccharides were reduced and analyzed by HPLC as described above. Anionic oligosaccharides bound to QAE were eluted with $70 \mathrm{mM} \mathrm{NaCl}$, desalted on Sephadex G-10, and concentrated. They were subsequently digested with alkaline phosphatase or treated with $0.1 \mathrm{~N} \mathrm{HCl}$ for $10 \mathrm{~min}$ at $100^{\circ} \mathrm{C}$ to remove the negative charge before reduction and HPLC analysis.

Spin columns. Samples in a volume of $50 \mu \mathrm{l}$ were applied to 200 $\mu l$ of Con A-Sepharose or QAE-Sephadex packed in spin columns and spun at 1,500 rpm in a microfuge tube for 1-2 min. Columns were washed four times with $200 \mu \mathrm{l}$ of water, and the bound material was eluted with $5 \times 200 \mu \mathrm{l}$ of preheated $\left(60^{\circ} \mathrm{C}\right) 100 \mathrm{mM} \alpha$-MeMan (for Con A-Sepharose) or $70 \mathrm{mM} \mathrm{NaCl}$ (for QAE).

Determination of $\left[{ }^{3} \mathrm{H}\right]$ mannose phosphates and sugar nucleotides. The Con A-Sepharose unbound material is expected to contain ${ }^{3} \mathrm{H}$-labeled mannose (Man), mannose-6-phosphate (Man-6-P), mannose-1-phosphate (Man-1-P), GDP-mannose (GDP-Man), and GDP-fucose (GDP-Fuc). We measured the amount of each of these components using a series of enzymatic reactions. All of the determinations are based on the ability of phosphomannose isomerase (PMI) to convert $\left[{ }^{3} \mathrm{H}\right]$ Man-6-P into fructose-6-P with the release of ${ }^{3} \mathrm{H}_{2} \mathrm{O}$ $(18,19)$, which can be removed by evaporation. The amount of Man6-P is measure by direct conversion to ${ }^{3} \mathrm{H}_{2} \mathrm{O}$ using PMI. Mannose is measured by converting it to Man-6-P with hexokinase. Man-1-P is converted to Man by alkaline phosphatase digestion, and then to Man-6-P with hexokinase. The remaining labeled material represents GDP-Man and GDP-Fuc. All reactions were carried out at $37^{\circ} \mathrm{C}$ for $1 \mathrm{~h}$ in a volume of $50 \mu \mathrm{l}$ containing the sample, $50 \mathrm{mM}$ Tris- $\mathrm{HCl}, \mathrm{pH}$ 8.0, $6 \mathrm{mM} \mathrm{MgCl}_{2}$, and $1 \mathrm{mU}$ of required enzymes, PMI, HK, or alkaline phosphatase $(20,21)$. Measurements were done on a single sample in the order described above, or by separate treatments of the sample divided into three aliquots. The results of both methods were the same. Conditions for these determinations were first worked out on individual standards or in mixtures containing various proportions of each component. In all cases, the conversions were $>95 \%$, and as little as $10 \%$ of any one product in the mixture could be accurately measured. A detailed description of the above method will be presented elsewhere (Panneerselvam, K., and H.H. Freeze, manuscript in preparation).

Labeling of fibroblasts with $\left[{ }^{3} \mathrm{H}\right] 2$-deoxyglucose. $\left[{ }^{3} \mathrm{H}\right] 2$-deoxyglucose uptake by fibroblasts was performed according to Asano et al. (22) with some modifications. The preincubation in the absence of serum was omitted, and the labeling was done in DMEM. Nearly confluent monolayers of fibroblasts in $35-\mathrm{mm}$ multiwell plates were incubated with $\left[{ }^{3} \mathrm{H}\right] 2$-deoxyglucose $(10 \mu \mathrm{Ci} / \mathrm{ml})$ in DMEM containing $2 \mathrm{mM}$ glutamine for $15 \mathrm{~min}$ at $37^{\circ} \mathrm{C}$. Labeling was terminated by the addition of $2 \mathrm{ml}$ of ice-cold PBS containing $10 \mathrm{mM}$ glucose and 0.3 $\mathrm{mM}$ phloretin, and the cells were rapidly washed three times with icecold PBS containing glucose and subsequently solubilized with $0.1 \%$ SDS. Aliquots of these were assayed for radioactivity and protein.

\section{Results}

Lipid and protein-bound oligosaccharides in CDGS cells. In previous studies, we found that two CDGS cell lines incorporated 2.5-5-fold less $\left[{ }^{3} \mathrm{H}\right]$ mannose into LLO and protein compared with normal cells (13). To extend these results, we analyzed the size of labeled oligosaccharides released from LLO or protein of controls and four CDGS cell lines. Normal cells make predominantly large LLO $\left(\mathrm{Glc}_{1-3} \mathrm{Man}_{9} \mathrm{GlcNAc}_{2}\right)$ (Fig. 1). Protein linked oligosaccharides released by PNGase F digestion had a size distribution similar to LLO, suggesting that little mannose processing occurs during labeling. This is supported by the finding that these oligosaccharides bind strongly to Con A-Sepharose and are not sialylated (not shown). In contrast, CDGS cells usually synthesize and transfer much smaller $\left(\mathrm{Man}_{4-6} \mathrm{GlcNAc}_{2}\right)$ oligosaccharides to proteins (Fig. 1). The LLOs do not appear to be glucosylated since $\alpha$-mannosidase digestion degrades them to free $\left[{ }^{3} \mathrm{H}\right]$ mannose and ManßGlcNAcßGlcNAc (HPLC data not shown). However, our results did not rule out the possibility that CDGS 
cells synthesize a smaller proportion of fully glucosylated LLO $\left(\mathrm{Glc}_{1-3} \mathrm{Man}_{5} \mathrm{GlcNAc}_{2}\right)$, which is preferentially transferred to protein. This kind of preferential transfer has been reported earlier in other cells that make truncated LLO (23). In $\sim 20 \%$ of the experiments under apparently identical labeling conditions, the CDGS cells synthesize and transfer mostly normal-sized LLOs (HPLC data not shown). Even in these cases, CDGS cells showed at least a threefold lower incorporation of $\left[{ }^{3} \mathrm{H}\right]$ mannose into LLO and protein compared with normal. The size variations were never seen in normal cells. These results show that underglycosylation of proteins is not due to a permanent inability to make the normal-sized LLO structure or to transfer it to protein.

Analysis of protein glycosylation using PNGase F and Endo $H$. Since isolation and analysis of LLO and protein bound $\mathrm{N}$-linked chains is time consuming, we used PNGase F to measure the amount of $\mathrm{N}$-linked glycosylation and Endo $\mathrm{H}$ to determine the size of newly transferred oligosaccharides. PNGase F cleaves nearly all known N-linked oligosaccharides from proteins, while Endo $\mathrm{H}$ cleaves high-mannose type oligosaccharides larger than $\mathrm{Man}_{5} \mathrm{GlcNAc}_{2}$ (14). Therefore, measuring the proportion of Endo $\mathrm{H}$-sensitive $\left[{ }^{3} \mathrm{H}\right]$ mannoselabeled chains measures the proportion of oligosaccharides $>$ $\mathrm{Man}_{5} \mathrm{GlcNAc}_{2}$

Duplicate cultures of normal, disease control, and four

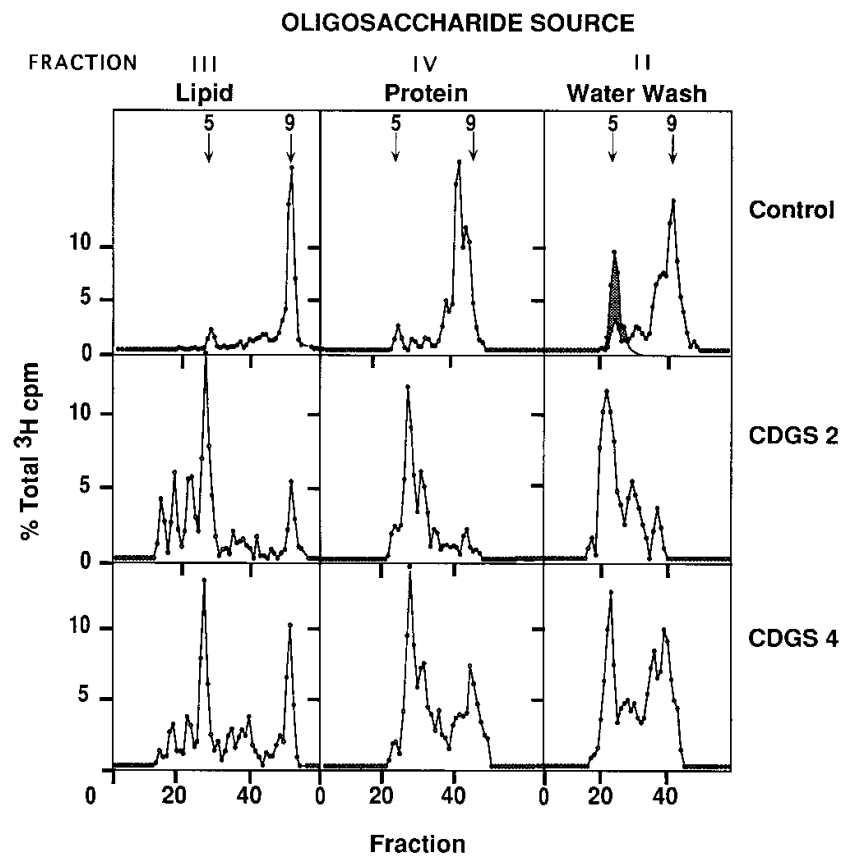

Figure 1. CDGS cells synthesize truncated LLO and transfer them to protein. Fibroblasts were labeled with $100 \mu \mathrm{Ci} / \mathrm{ml}\left[{ }^{3} \mathrm{H}\right]$ mannose for 30 min, and the neutral oligosaccharides from fractions II (water wash), III (LLO), and IV (protein) were isolated and processed as described in Methods. Sizes of the oligosaccharides were analyzed using an amine adsorption HPLC column that separates oligosaccharides according to size, with larger eluting later. 1-ml fractions were collected and counted for radioactivity. The shaded area in the water wash of control indicates the elution pattern of Con A-bound anionic oligosaccharides derived from fraction II after dephosphorylation with alkaline phosphatase. The elution position of the standards are indicated by arrows labeled with $5\left(\mathrm{Man}_{5} \mathrm{GlcNAc}_{2}\right)$ and 9 $\left(\mathrm{Glc}_{1-3} \mathrm{Man}_{9} \mathrm{GlcNAc}_{2}\right)$.
Table I. Labeling of Control and CDGS Fibroblasts with $\left[{ }^{3} \mathrm{H}\right]$ Mannose and $\left[{ }^{35}\right.$ S]Methionine*

\begin{tabular}{lccc}
\hline Cell line & ${ }^{3} \mathrm{H}^{\beta 5} \mathrm{~S}^{\ddagger}$ & $\begin{array}{c}\text { \% PNGase F } \\
\text { sensitive }\end{array}$ & $\begin{array}{c}\text { \% Endo H } \\
\text { sensitivel }\end{array}$ \\
\hline Normal & $159(100)$ & 86 & 61 \\
Disease control & $164(103)$ & 84 & 63 \\
CDGS 1 & $53(33)$ & 85 & 16 \\
2 & $15(9)$ & 83 & 10 \\
3 & $36(22)$ & 87 & 26 \\
4 & $52(32)$ & 83 & 24 \\
\hline
\end{tabular}

* Labeling for $60 \mathrm{~min}$. and incorporation into protein was determined as described in Methods. ${ }^{\ddagger}$ Numbers in parentheses indicate the percentage of normal which is defined as 100 , and other samples are presented as a percentage of this value. ${ }^{\S}$ Defined as the percentage of total TCA-precipitable ${ }^{3} \mathrm{H}$ released by PNGase F. "Defined as the percentage of total TCA-precipitable ${ }^{3} \mathrm{H}$ released by Endo $\mathrm{H}$.

CDGS cell lines were labeled with $\left[{ }^{3} \mathrm{H}\right]$ mannose and $\left[{ }^{35} \mathrm{~S}\right] \mathrm{me}-$ thionine, and a portion of the lysates was analyzed by TCA precipitation before and after Endo $\mathrm{H}$ or PNGase $\mathrm{F}$ digestions. The results of one representative labeling are shown in Table I. In all CDGS cells, $\left[{ }^{3} \mathrm{H}\right]$ mannose incorporation into protein was 3-20-fold less than controls when normalized either to protein content or to $\left[{ }^{35} \mathrm{~S}\right]$ methionine incorporation. PNGase $\mathrm{F}$ digestion released $83-87 \%$ of the $\left[{ }^{3} \mathrm{H}\right]$ mannose from all cell lysates, and Endo $\mathrm{H}$ digestion released $60-70 \%$ of $\left[{ }^{3} \mathrm{H}\right] \mathrm{man}-$ nose from protein of normal and disease control cells. In contrast, Endo H released only 16-29\% from CDGS cell proteins. The smaller size of the Endo H-resistant oligosaccharides was confirmed by HPLC (data not shown).

Since cell passage number and density can influence the size of the LLO (24) and the amount of $\left[{ }^{3} \mathrm{H}\right]$ mannose incorpo-

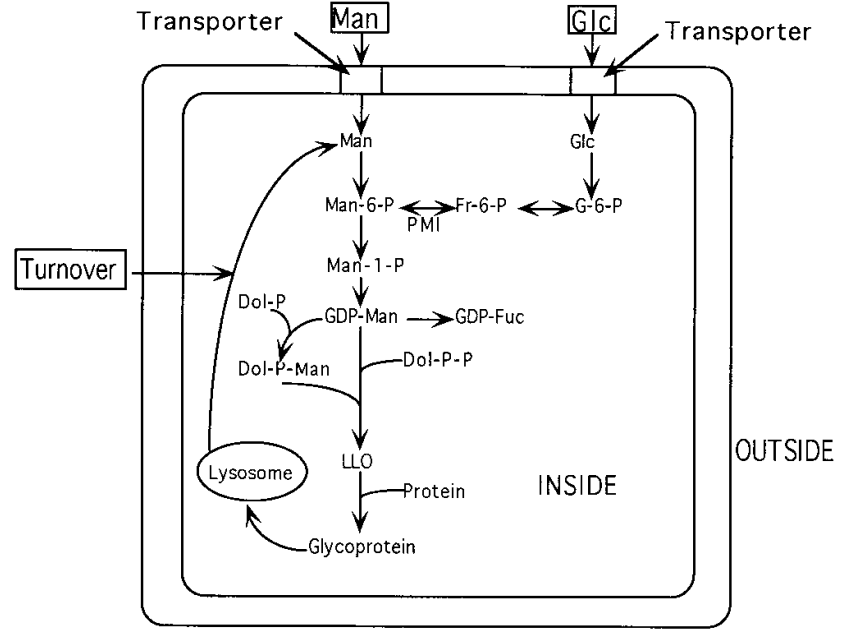

Figure 2. Potential sources of mannose and its metabolism in relation to protein glycosylation. Mannose for $\mathrm{N}$-linked glycosylation may $(a)$ come from glucose through a pathway involving PMI; $(b)$ plasma mannose may be transported (Transporter) inside the cell; or $(c)$ it may also be salvaged from LLO degradation and typical oligosaccharide processing (Turnover). The relative contribution of mannose from each of these sources is unknown. Mannose is converted into Man-6-P and then to Man-1-P, which is used to synthesize GDP-Man and dol-P-Man for LLO. INSIDE and OUTSIDE refer to the cell. 


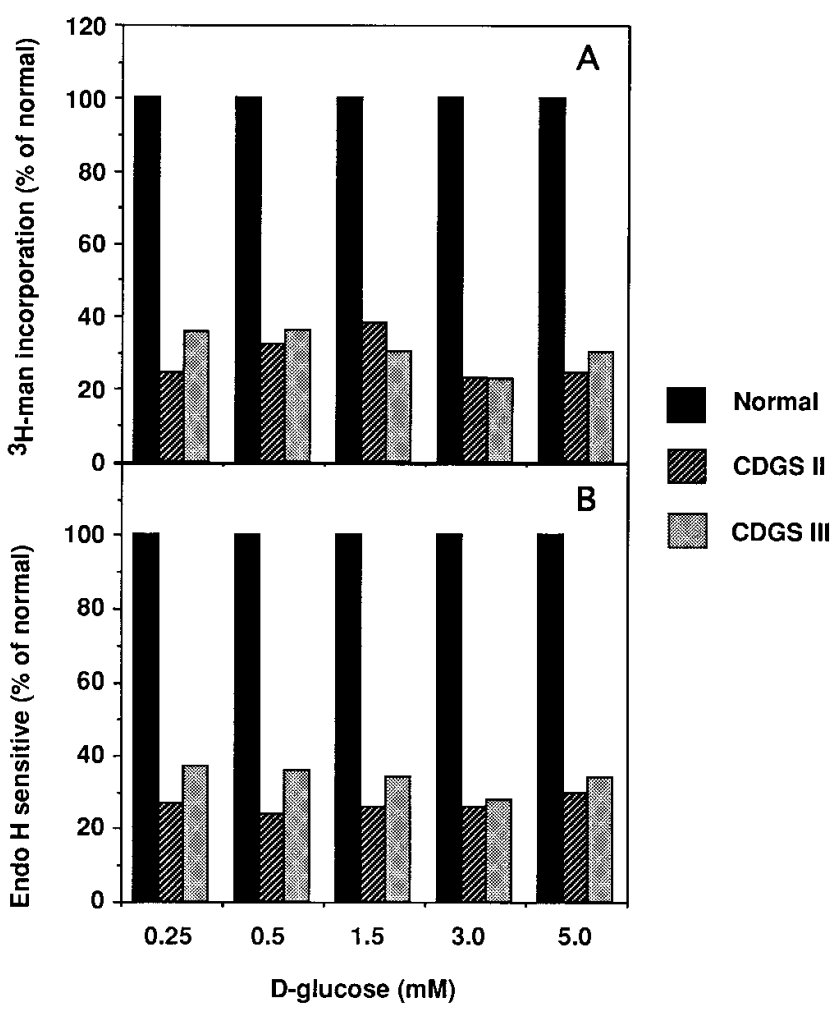

Figure 3. D-Glucose has no effect on the underglycosylation and oligosaccharide size of CDGS cells. Fibroblasts were labeled with 20 $\mu \mathrm{Ci} / \mathrm{ml}\left[{ }^{3} \mathrm{H}\right]$ mannose for $1 \mathrm{~h}$ with increasing amounts of D-glucose. The incorporation into glycoprotein was measured by TCA precipitation, and the oligosaccharide size was measured by Endo H sensitivity as described in Methods. TCA precipitable counts were normalized to protein content and taken as the total incorporation into glycoproteins (glycosylation). The difference in the TCA precipitable counts before and after Endo $\mathrm{H}$ digestion represents the oligosaccharides with structure $>\operatorname{Man}_{5} \mathrm{GlcNAc}_{2}$ (Endo H sensitive). Glycosylation $(A)$ and Endo $\mathrm{H}$ sensitivity $(B)$ in normal cells are taken as $100 \%$, and those in CDGS patients are shown as a percentage of this value.

ration into protein, we compared these parameters in normal, disease control, and CDGS cells at different passages. Cells of the same passage, from widely different passages or at different densities, were labeled on the same day with $\left[{ }^{3} \mathrm{H}\right]$ mannose and digested with PNGase F and Endo H. Regardless of the passage number and cell density, normal and disease control cells always make primarily ( $80 \%$ ) Endo H-sensitive oligosaccharides. In contrast, the proportion of Endo H-sensitive oligosaccharides varied from $10-80 \%$ in CDGS cells, and had a 3 -10-fold decrease in $\left[{ }^{3} \mathrm{H}\right]$ mannose incorporation. It appears that $\mathrm{N}$-linked oligosaccharide synthesis in CDGS cells under these conditions is inherently variable. The control and CDGS cells grew at the same rate (with $60 \mathrm{~h}$ doubling time), and there were no obvious differences in the cell size, morphology, or protein content compared with the controls. Since fibroblasts from normal and each of three different disease control cells behaved the same in these experiments, we sometimes used only the disease control cells or normal cells in subsequent experiments.

Glycosylation in CDGS cells resembles glucose starvation. The combination of underglycosylation and truncated LLO

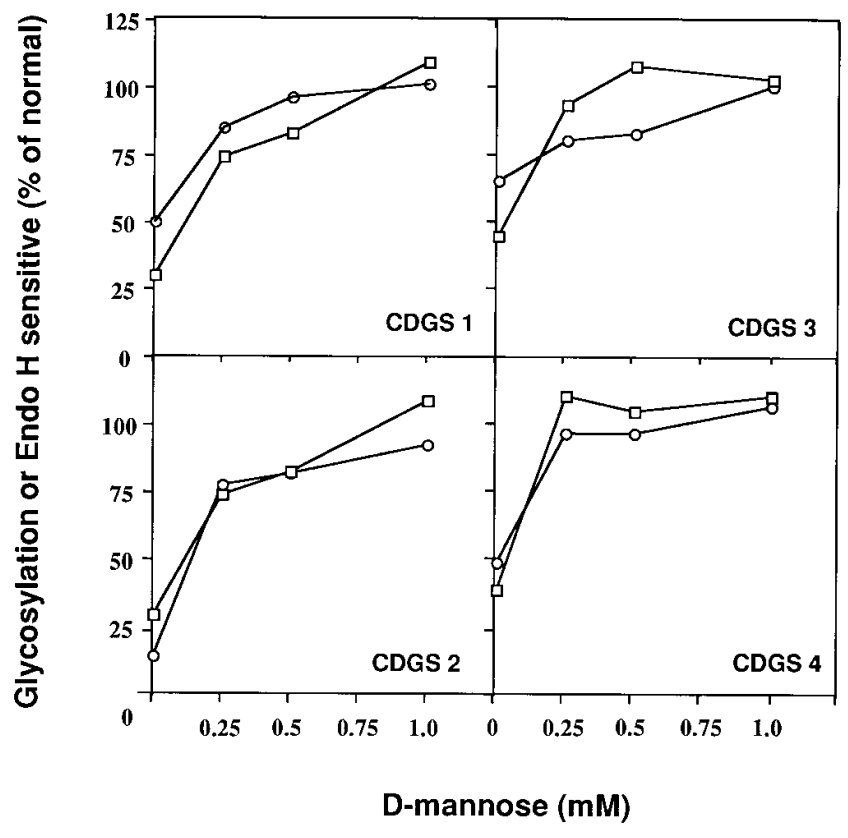

Figure 4. Correction of underglycosylation and oligosaccharide size by D-mannose in CDGS cells. Fibroblast cultures were incubated with $20 \mu \mathrm{Ci} / \mathrm{ml}$ of $\left[{ }^{3} \mathrm{H}\right]$ mannose and increasing amounts of nonlabeled D-mannose for $1 \mathrm{~h}$, and the ${ }^{3} \mathrm{H}$-label incorporation into glycoprotein $(\square)$ and Endo $\mathrm{H}$ sensitivity $(\bigcirc)$ were measured by TCA precipitation as described in the legend to Fig. 3.

size has been seen in cells during glucose starvation (24-32). These cells mostly synthesize $\mathrm{Man}_{5} \mathrm{GlcNAc}_{2}$ and in some cases fully glucosylated LLO $\left(\mathrm{Glc}_{3} \mathrm{Man}_{5} \mathrm{GlcNAc}_{2}\right)(31,32)$. There is a considerable cell-type variation in the degree of underglycosylation and time required to see the effects, but, in all cases, only the addition of either glucose or mannose corrects both of the glycosylation defects. Although the basis of the glucose starvation effect is unknown, the similar efficacy of glucose and mannose can be easily explained by the assumption that the bulk of Man-6-P used for glycoprotein synthesis is derived from glucose through a pathway involving PMI (Fig. 2).

Based on this rationale, we considered the possibility that CDGS cells have insufficient intracellular glucose, perhaps induced by replacing the normal glucose $(5.0 \mathrm{mM})$ medium with labeling medium that contains $0.5 \mathrm{mM}$ glucose. This medium is commonly used to improve $\left[{ }^{3} \mathrm{H}\right]$ Man labeling efficiency by reducing the mutual competition of mannose and glucose for the hexose transporters $(18,33)$. To test this possibility, the glucose concentration was increased up to $5 \mathrm{mM}$ during or $1 \mathrm{~h}$ before the labeling, but this did not have any effect on either underglycosylation or oligosaccharide size (Fig. 3) in CDGS cells. These results show altered glycosylation in CDGS cells is not identical to that seen in glucose starvation.

Addition of D-mannose corrects oligosaccharide size and $\left[{ }^{3} H\right]$ mannose incorporation into proteins. In contrast, when CDGS cell lines were labeled in the presence of increasing amounts of exogenous D-mannose, both the decreased incorporation of $\left[{ }^{3} \mathrm{H}\right]$ mannose and Endo $\mathrm{H}$ sensitivity are corrected in parallel (Fig. 4). Addition of mannose to CDGS cells corrected the LLO size to $\mathrm{Glc}_{1-3} \mathrm{Man}_{9} \mathrm{GlcNAc}_{2}$ (Fig. 5), and these normalsized chains were transferred to protein (data not shown). In- 


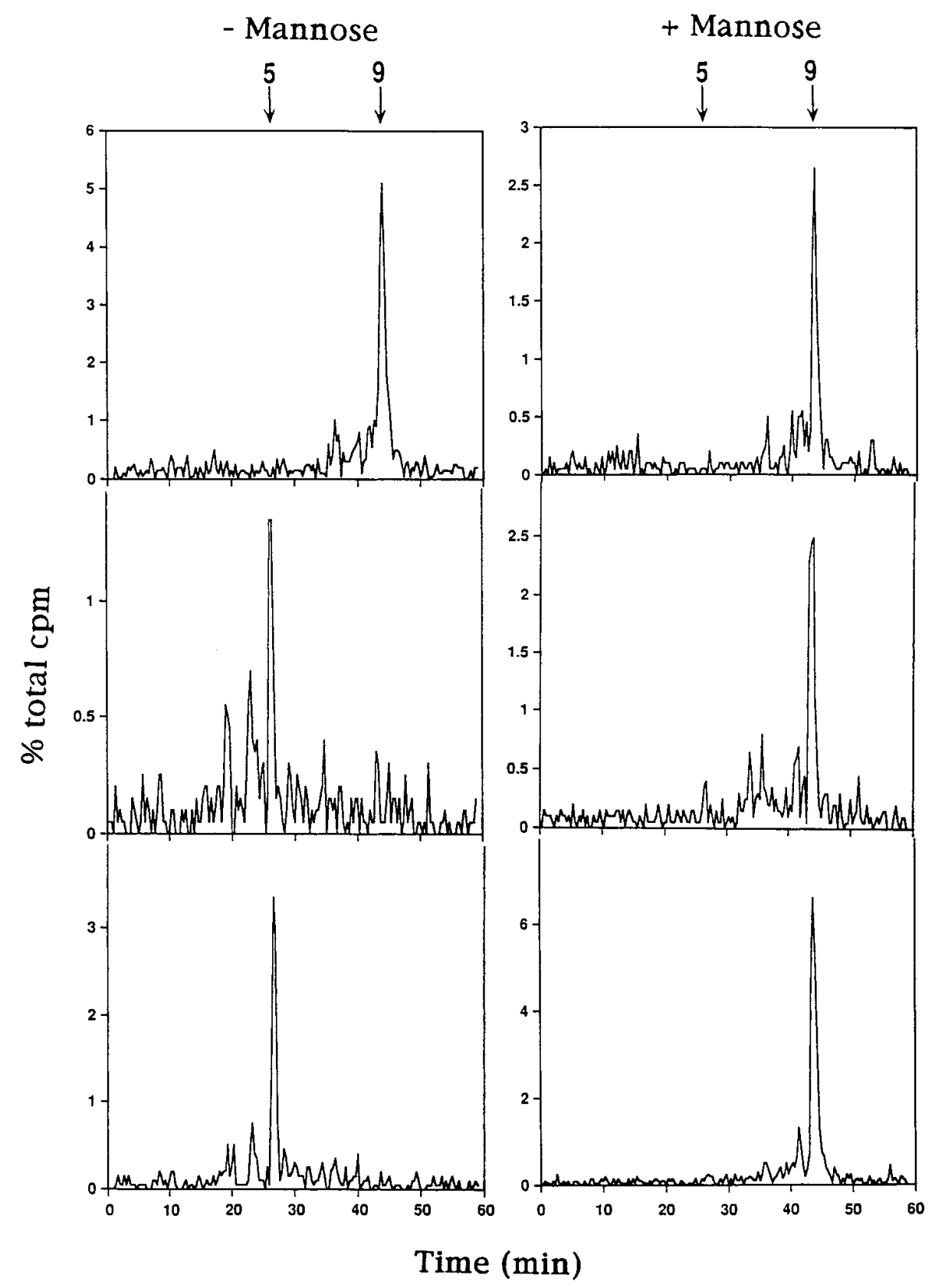

\section{Normal}

CDGS 2 Figure 5. D-Mannose corrects LLO size. Normal fibroblasts or CDGS 2 and CDGS 3 fibroblasts were labeled with $150 \mu \mathrm{Ci} / \mathrm{ml}$ $\left[{ }^{3} \mathrm{H}\right]$ mannose in the presence and absence of $1 \mathrm{mM}$ unlabeled D-mannose for $30 \mathrm{~min}$. The LLOs were isolated as described in Methods. Oligosaccharides (1,500-3,000-cpm aliquots) were applied to an amine adsorption HPLC column CDGS 3 connected to a radioactivity flow detector. Profiles show $\%{ }^{3} \mathrm{H}$ vs elution time for LLO from control or CDGS fibroblasts. The elution positions of standards are indicated by arrows labeled with 5 $\left(\mathrm{Man}_{5} \mathrm{GlcNAc}_{2}\right)$ and 9 $\left(\mathrm{Glc}_{1-3} \mathrm{Man}_{9} \mathrm{GlcNAc}_{2}\right)$.

creased mannose does not alter the size of the oligosaccharides made by normal cells. The effect of mannose on CDGS cells was seen even in the presence of $5 \mathrm{mM}$ glucose (Fig. 6), showing that the effect is exclusive for mannose under these conditions. L-Mannose is also ineffective, presumably since it cannot be transported and/or phosphorylated by hexokinase.

Effects of long-term incubation of mannose on cells. To determine whether prolonged incubation with mannose corrects the altered glycosylation, CDGS fibroblasts were grown in $1 \mathrm{mM}$ D-mannose for up to $10 \mathrm{~d}$ before labeling. The exogenous mannose was removed and cells were labeled with only $\left[{ }^{3} \mathrm{H}\right]$ mannose $(1 \mu \mathrm{M})$ in the presence of $0.5 \mathrm{mM}$ glucose. Under these conditions, the amount of incorporation and Endo $\mathrm{H}$ sensitivity of the labeled oligosaccharides were the same as those of cells that had never been grown in mannose (data not shown). This finding supports the idea that mannose must be continually present to correct the underglycosylation and the truncated size of the oligosaccharides in CDGS fibroblasts.

Fractionation and analysis of $\left[{ }^{3} H\right]$ mannose-labeled products in control and CDGS lines. The correction of abnormal glycosylation in CDGS cells by mannose suggested that there might be a specific deficiency in one or more of the intermediates leading to LLO. To search for a specific deficiency, we analyzed a broad range of $\left[{ }^{3} \mathrm{H}\right]$ mannose-labeled products from control and four CDGS cells.

Passage- and density-matched control and CDGS cells were labeled for $30 \mathrm{~min}$ with $\left[{ }^{3} \mathrm{H}\right]$ mannose as described in Methods, and four fractions (I-IV) were prepared in the following order: The first (I) is a $\mathrm{CHCl}_{3} / \mathrm{MeOH}(2: 1 \mathrm{vol} / \mathrm{vol})$ extract that contains mostly small lipid-linked molecules such as 


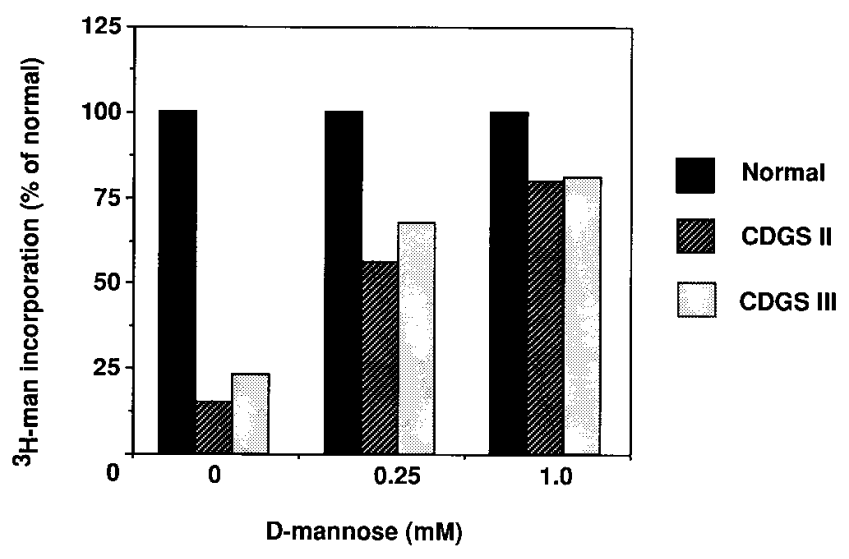

Figure 6. Effect of D-mannose on the underglycosylation of CDGS cells at a higher concentration of glucose. Fibroblasts were labeled with $20 \mu \mathrm{Ci} / \mathrm{ml}\left[{ }^{3} \mathrm{H}\right]$ mannose for $1 \mathrm{~h}$ in DMEM containing $5 \mathrm{mM}$ glucose and increasing amount of unlabeled D-mannose. Cell lysates were precipitated with TCA, counted for radioactivity, and normalized to protein content. $\left[{ }^{3} \mathrm{H}\right]$ Mannose incorporation into glycoprotein in normal is taken as $100 \%$ and that in CDGS patients is presented as a percentage of this value.

dol-P-Man. The second (II) is a water wash containing lowmolecular weight intermediates, and perhaps free oligosaccharides. The third (III) is a $\mathrm{CHCl}_{3} / \mathrm{MeOH} / \mathrm{H}_{2} \mathrm{O}(10: 10: 3 \mathrm{vol} / \mathrm{vol})$ extraction that contains the LLO, and, finally, an insoluble pellet, fraction IV, contains protein-bound N-linked oligosaccharides. As shown in Table II, CDGS cells incorporate 3-20-fold less $\left[{ }^{3} \mathrm{H}\right]$ mannose into protein (fraction IV) and 3-40-fold less in LLO (fraction III) compared with control. The size of the oligosaccharides from lipid or protein in CDGS cells is $\mathrm{Man}_{4-6} \mathrm{GlcNAc}_{2}$ (data not shown). The ${ }^{3} \mathrm{H}$ protein/LLO ratio in CDGS cells is equal to or greater than control, showing that the CDGS cells use the reduced amount of LLO as efficiently as control cells.

Fraction I. The majority of labeled material in fraction I is dol-P-Man, and the amount is similar in CDGS cells and the control. This was surprising in view of the reduction in the amount of label in all of the other fractions analyzed.

Fraction II, Con A-bound material. The amount of label in fraction II is also $3-10$-fold lower in CDGS cells than in the control. This fraction should contain ${ }^{3} \mathrm{H}$-labeled Man and metabolic intermediates Man-6-P, Man-1-P, GDP-Man, and GDP-
Fuc, but $\sim 35-60 \%$ of the label in fraction II from each cell line bound to Con A-Sepharose. This material is composed of free oligosaccharides rather than glycopeptides, since it did not bind to cation exchange resin (Dowex-50). The size of these oligosaccharides also closely resembles that of those derived from protein-bound oligosaccharides (shown in Fig. 1), and they are most likely cleaved from protein or LLO as reported by others (34-40).

About $15-40 \%$ of the Con A-Sepharose-bound material also binds to QAE-Sephadex and is eluted by $70 \mathrm{mM} \mathrm{NaCl}$, suggesting that this material contains two negative charges (41). Alkaline phosphatase digestion, or mild acid hydrolysis $\left(0.1 \mathrm{~N} \mathrm{HCl}, 10 \mathrm{~min}, 100^{\circ} \mathrm{C}\right)$ eliminates binding to the resin. These molecules probably have a phosphomonoester on the reducing GlcNAc and were derived from LLO by pyrophosphatase-type cleavage. The alkaline phosphatase-neutralized oligosaccharides from the control are small $\left(\mathrm{Man}_{5} \mathrm{GlcNAc}_{2}-\right.$ size; Fig. 1, top right panel, shaded area), and not typical of the entire LLO pattern. This shows that selected LLOs are preferentially hydrolyzed in control cells. In CDGS, the size of the anionic oligosaccharides is also small, and, in this case, they reflect the truncated LLO pattern (data not shown).

The amount of Con A-Sepharose-bound material differs in each cell line (Table III), but it is nearly the same proportion of the total ${ }^{3} \mathrm{H}$ label in all cells. This shows that decrease of ${ }^{3} \mathrm{H}$ in glycoproteins seen in CDGS cells is not due to accelerated degradation of either LLO or newly synthesized glycoproteins.

Fraction II, not bound to Con $A$. The amounts of ${ }^{3} \mathrm{H}-$ labeled Man, Man-6-P, Man-1-P, and GDP-Man + GDP-Fuc in fraction II were determined as described in Methods (Table III). The amount of each and the total amount of cell-associated ${ }^{3} \mathrm{H}$ (total counts per minute in fractions I-IV; Table II) are much lower in all CDGS cells. Since these decreases correspond quite well to the decrease in protein glycosylation and LLO, it appears that CDGS cells are not deficient in any of the biosynthetic steps leading to the synthesis of LLO or its transfer to protein. Once $\left[{ }^{3} \mathrm{H}\right]$ mannose is inside the cell, it appears to be metabolized normally. Thus, it appears that $\left[{ }^{3} \mathrm{H}\right]$ mannose itself may be limited.

Mannose entry in CDGS cells is impaired. As shown in Fig. 7, CDGS cells are two- to threefold slower in $\left[{ }^{3} \mathrm{H}\right]$ mannose uptake than the normal cells. Mannose uptake is completely blocked by phloretin, showing that it is transporter mediated (42). Since the plasma membrane glucose transporters are able

Table II. Distribution of $\left.{ }^{3} H\right]$ Mannose in Various Fractions of Control and CDGS Fibroblasts*

\begin{tabular}{|c|c|c|c|c|c|c|c|}
\hline Cell line & $\begin{array}{c}2: 1 \mathrm{CHCl}_{3} / \mathrm{MeOH} \\
\text { Fraction I }\end{array}$ & $\begin{array}{l}\text { Water wash } \\
\text { Fraction II }\end{array}$ & $\begin{array}{c}\text { LLO } \\
\text { Fraction III }\end{array}$ & $\begin{array}{c}\text { Protein } \\
\text { Fraction IV }\end{array}$ & $\begin{array}{l}\text { Total }{ }^{3} \mathrm{H} \text { in cells } \\
\text { Fractions I-IV }\end{array}$ & Protein/LLO & \% Endo H sensitive ${ }^{\ddagger}$ \\
\hline & \multicolumn{5}{|c|}{${ }^{3} \mathrm{H} \mathrm{cpm} \times 10^{-4} / \mathrm{mg}$ protein } & & \\
\hline Disease control & $41.9(37.7)^{\S}$ & 685.5 & 418.0 & 613.9 & $1,759.3(100.0)^{\|}$ & 1.46 & 83 \\
\hline CDGS 1 & $36.7(29.4)^{\S}$ & 158.5 & 15.7 & 105.3 & $316.2(18.0)^{\|}$ & 6.60 & 31 \\
\hline 2 & $41.0(35.7)^{\S}$ & 80.5 & 10.9 & 34.4 & $166.8(9.5) \|$ & 3.10 & 16 \\
\hline 3 & $35.3(33.5)^{\S}$ & 272.0 & 78.7 & 202.5 & $588.5(33.4)^{\|}$ & 2.50 & 29 \\
\hline 4 & $51.5(36.4)^{\S}$ & 160.6 & 17.9 & 93.3 & $323.3(18.3)^{\|}$ & 5.20 & 25 \\
\hline
\end{tabular}

\footnotetext{
* Duplicate cultures were labeled consecutively with $\left[{ }^{3} \mathrm{H}\right]$ Mannose for $30 \mathrm{~min}$ and fractionated as described in Methods. ${ }^{\S}$ Dol-P-Man content.

" Numbers in parentheses indicate the percentage of control which is defined as 100, and CDGS samples are presented as a percentage of this value.

${ }^{\ddagger}$ Defined as the percentage of total TCA-precipitable ${ }^{3} \mathrm{H}$ released by Endo $\mathrm{H}$.
} 
Table III. Detailed Analysis of Fraction II from $\left.\beta^{\beta} H\right]$ Mannose-labeled Control and CDGS Fibroblasts*

\begin{tabular}{|c|c|c|c|c|c|c|c|}
\hline \multirow[b]{2}{*}{ Cell line } & \multicolumn{2}{|c|}{ Con A bound } & \multicolumn{5}{|c|}{ Con $\mathrm{A}$ unbound } \\
\hline & Total & Anionic & Total & Man & Man-6-P & Man-1-P & GDP-Man + GDP-Fuc \\
\hline & \multicolumn{7}{|c|}{$\mathrm{cpm} \times 10^{-4} / \mathrm{mg}$ protein } \\
\hline Disease control & $376.4(100.0)^{\ddagger}$ & 82.8 & $309.1(100.0)^{\ddagger}$ & 70.7 & 60.9 & 49.8 & 127.7 \\
\hline CDGS 1 & $74.2(20.0)^{\ddagger}$ & 29.7 & $84.3(27.2)^{\ddagger}$ & 11.1 & 31.7 & 15.2 & 26.6 \\
\hline 2 & $34.4(9.1)^{\ddagger}$ & 13.7 & $46.1(14.9)^{\ddagger}$ & 9.5 & 12.9 & 4.8 & 18.9 \\
\hline 3 & $142.5(37.8)^{\ddagger}$ & 54.2 & $129.5(41.9)^{\ddagger}$ & 18.2 & 35.2 & 25.2 & 50.9 \\
\hline 4 & $60.1(15.9)^{\ddagger}$ & 24.0 & $100.5(32.5)^{\ddagger}$ & 16.1 & 26.7 & 17.7 & 40.2 \\
\hline
\end{tabular}

* Fraction II from the same experiment described in Table II was separated into Con A-Sepharose-bound and unbound fractions and analyzed as described in Methods. ${ }^{*}$ Numbers in parentheses indicate the percentage of control which is defined as 100, and CDGS samples are presented as a percentage of this value.

to transport both mannose and glucose (43-45), one possible explanation for decreased $\left[{ }^{3} \mathrm{H}\right]$ mannose uptake is a defect in one of these transporters. To determine this, we used a standard $\left[{ }^{3} \mathrm{H}\right] 2$-deoxyglucose transport assay as a general measure of hexose uptake. All the CDGS cells showed only a $10 \%$ decrease in $\left[{ }^{3} \mathrm{H}\right] 2$-deoxyglucose uptake except in one experiment, where one CDGS cell line showed a 30\% decrease (data not shown) compared with normal cells. This makes it unlikely that the transporters measured by $\left[{ }^{3} \mathrm{H}\right] 2$-deoxyglucose uptake are responsible for the more pronounced decrease in $\left[{ }^{3} \mathrm{H}\right] \mathrm{man}$ nose uptake by CDGS cells.

Addition of D-mannose corrects $\left[{ }^{3} H\right]$ mannose incorporation into LLO precursors fractions. To determine whether increased exogenous mannose normalized the incorporation into various fractions, normal and two CDGS cell lines were labeled in the absence and presence of $1 \mathrm{mM}$ exogenous D-mannose, and the products were analyzed as before (Table IV). In this experiment the amount of dol-P-Man is 1.5-2-fold less than in normal cells. This was in contrast to four previous experiments where CDGS and normals had the same amount of dol-P-Man. All the other fractions (II-IV) had 2-20-fold less label than the normal, and addition of mannose produces

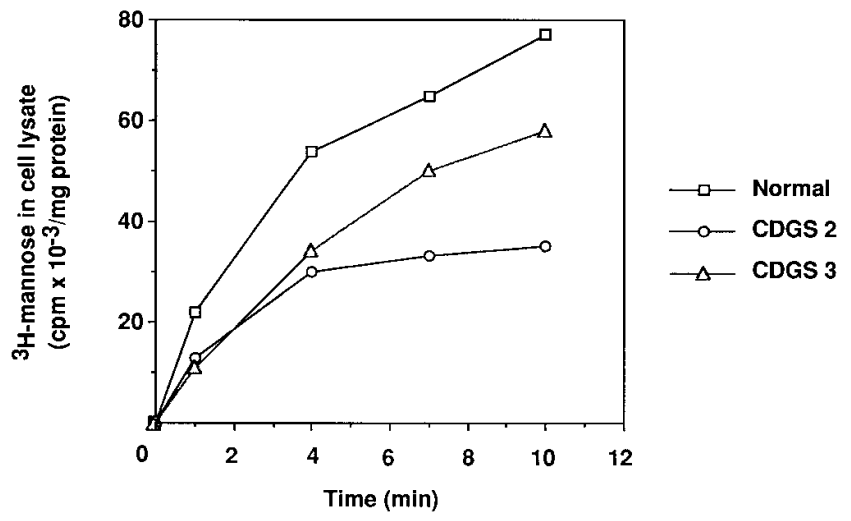

Figure 7. Measurement of initial velocities of $\left[{ }^{3} \mathrm{H}\right]$ mannose uptake. Cells in multiwell plates were labeled with $20 \mu \mathrm{Ci} / \mathrm{ml}$ of $\left[{ }^{3} \mathrm{H}\right]$ mannose for times shown in the figure. At each point, medium was removed, and cells were washed three times with cold PBS. Cells were solubilized in $0.5 \%$ SDS, and cell-associated $\left[{ }^{3} \mathrm{H}\right]$ mannose was normalized to protein. normal levels. These results support the idea that CDGS fibroblasts are limited in the availability of mannose inside the cell for N-linked protein glycosylation.

\section{Discussion}

Type I CDGS patients show reduced N-linked glycosylation of many proteins (1). In previous studies, fibroblasts from two CDGS patients incorporated less $\left[{ }^{3} \mathrm{H}\right]$ mannose into both glycoproteins and LLO compared with controls (13). Based on these results, we suggested that there was a deficiency in the synthesis of LLO. Another possibility is that the LLO is rapidly degraded, but this is ruled out by the finding that the proportion of free oligosaccharides is nearly the same in CDGS and controls. We also found that cells from CDGS patients usually make smaller LLO species $\left(\mathrm{Man}_{4-6} \mathrm{GlcNAc}_{2}\right)$ and always incorporate less $\left[{ }^{3} \mathrm{H}\right]$ mannose into glycoproteins. Recently, another group also showed that one CDGS cell line synthesizes a truncated LLO and incorporates less $\left[{ }^{3} \mathrm{H}\right] \mathrm{man}$ nose into protein (46). In some of our experiments, CDGS cells made mostly normal-sized LLO, showing that the defect in CDGS is not in one of the LLO mannosyl transferases. We also found that CDGS cells usually synthesize a normal amount of dol-P-Man, suggesting that the defect in CDGS is not the same as in Thy E cells that invariably synthesize a specific LLO $\left(\mathrm{Glc}_{3} \mathrm{Man}_{5} \mathrm{GlcNAc}_{2}\right)$ due to dol-P-Man synthase deficiency (47).

Similar aberrant LLO synthesis and underglycosylation are seen in cultured cells during glucose starvation (24-32). This well-documented but unexplained phenomenon shows considerable cell-type variation. Normal glycosylation is restored by the addition of $50 \mu \mathrm{M}$ of either glucose or mannose but not by any other sugars or by pyruvate and glutamine (24-27). In baby hamster kidney cells, galactose also partially reverses the starvation effects (25). Glucose-starved Chinese hamster ovary cells also show a drastic reduction in dol-P-Man, and in this way they resemble dol-P-Man synthase deficiency seen in Thy E cells $(31,47)$. More recently, similar effects of glucose limitation have been seen in the underglycosylation of recombinant proteins (48-51). Although the physiological basis of this phenomenon remains unknown, the weight of the evidence seems to point to a deficiency in obtaining or generating mannose for glycoprotein synthesis. 


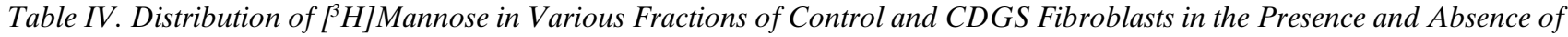
Unlabeled D-Mannose*

\begin{tabular}{|c|c|c|c|c|c|c|}
\hline Cell line & $\begin{array}{l}\text { 2:1 } \mathrm{CHCl}_{3} / \mathrm{MeOH} \\
\text { Fraction I }\end{array}$ & $\begin{array}{l}\text { Water wash } \\
\text { Fraction II }\end{array}$ & $\begin{array}{c}\text { LLO } \\
\text { Fraction III }\end{array}$ & $\begin{array}{l}\text { Protein } \\
\text { Fraction IV }\end{array}$ & $\begin{array}{l}\text { Total }{ }^{3} \mathrm{H} \text { in cells } \\
\text { Fractions I-IV }\end{array}$ & \% Endo H sensitive \\
\hline & \multicolumn{5}{|c|}{${ }^{3} \mathrm{H} \mathrm{cpm} \times 10^{-3} / \mathrm{mg}$ protein } & \\
\hline \multicolumn{7}{|l|}{ - Man } \\
\hline Normal & $170.7(138.3)^{\S}$ & 1340.0 & 354.2 & 67.7 & $1932.6(100.0)^{\|}$ & 80 \\
\hline CDGS 1 & $126.9(100.2)^{\S}$ & 226.0 & 90.5 & 15.3 & $458.7(23.7)^{\|}$ & 22 \\
\hline 2 & $83.4(61.7)^{\S}$ & 169.5 & 28.8 & 13.3 & $295.0(15.3)^{\|}$ & 34 \\
\hline \multicolumn{7}{|c|}{ + 1 mM Man } \\
\hline Normal & $48.2(39.5)^{\S}$ & 368.8 & 14.8 & 9.8 & $441.6(100.0)^{\|}$ & 82 \\
\hline CDGS 1 & $37.8(32.2)^{\S}$ & 316.8 & 13.0 & 8.7 & $376.4(85.2)^{\|}$ & 85 \\
\hline 2 & $34.6(30.1)^{\S}$ & 268.5 & 16.3 & 10.2 & $329.7(74.6)^{\|}$ & 78 \\
\hline
\end{tabular}

* Fibroblast cultures were labeled with $150 \mu \mathrm{Ci} / \mathrm{ml}\left[{ }^{3} \mathrm{H}\right]$ mannose in the presence and absence of unlabeled D-mannose for 30 min and fractionated as described in Methods. ${ }^{\ddagger}$ Defined as the percentage of total TCA-precipitable ${ }^{3} \mathrm{H}$ released by Endo H. ${ }^{\S}$ Dol-P-Man content. ${ }^{\|}$Numbers in parentheses indicate the percentage of normal which is defined as 100, and CDGS samples are presented as a percentage of this value.

Based on the similarity to the glucose starvation effect, it was surprising that mannose, but not glucose, corrects the altered glycosylation in CDGS cells, since the bulk of endogenous mannose for glycoprotein synthesis is assumed to be derived from glucose through PMI (Fig. 2). However, we have already shown that this enzyme and others involved in this pathway (hexokinase and phosphoglucose isomerase) appear to be normal in CDGS cells (21). This may mean that glucose is not actually the predominant source of mannose for glycoprotein synthesis and that adding mannose to CDGS cells bypasses the deficiency from the other pathway(s). In this regard, it is important to note that the quantitative contribution of glucose-derived mannose in mammalian glycoprotein synthesis has not actually been established. Cells may acquire mannose in other ways (Fig. 2). One possible source is from the plasma, which contains $\sim 30-50 \mu \mathrm{M}$ mannose (52). Another is from the degradation of pinocytosed serum glycoproteins or from the turnover of endogenous glycoproteins and oligosaccharides. Mannose released from LLO degradation and oligosaccharide "trimming" alone could total $80 \%$ of the mannose initially incorporated into LLO. Mammalian cells are equipped with an array of $\alpha$-mannosidases to degrade many linkages and generate free mannose (53). The absence of solid results on the origin of mannose in higher organisms is further complicated by untested assumptions and extrapolations from other systems. For instance, although PMI is ubiquitous, the effects of a gene deletion have not been tested in mammalian cells. Loss of PMI in yeast is lethal (54), but the much larger metabolic load and 100-fold higher specific activity in yeast than in mammalian cells may make such a comparison unwarranted.

Since glucose and mannose can be carried by the same hexose transporter, a possible explanation for decreased mannose labeling in CDGS is a defective glucose transporter. This is unlikely since CDGS fibroblasts were only slightly less efficient in $\left[{ }^{3} \mathrm{H}\right] 2$-deoxyglucose transport compared with normal cells. The decrease could be a secondary effect of transporter underglycosylation (55). The more dramatic two- to threefold decrease in $\left[{ }^{3} \mathrm{H}\right]$ mannose entry into the cells may partially explain the variable decrease in $\left[{ }^{3} \mathrm{H}\right]$ mannose incorporation in CDGS cells. This observation could mean that mannose enters the cell using a separate transporter that does not transport $\left[{ }^{3} \mathrm{H}\right] 2$-deoxyglucose.

We found that CDGS cells also had considerably less ${ }^{3}$ H-labeled intermediates, GDP-Man + GDP-Fuc, Man-1-P, Man-6-P, and Man, compared with controls, and these decreases corresponded well to the lowered amount of LLO and protein-bound oligosaccharides. The exception to this pattern is dol-P-Man, which seems to be much closer to normal in CDGS cells. The reasons for this are unknown, but dol-P-Man synthase may preferentially use GDP-Man because of a lower $K_{\mathrm{m}}$, or dol-P-Man may accumulate because of lack of utilization in making larger LLOs. Alternatively, dol-P-Man might use a separate pool of GDP-Man from that used in the other reactions.

Could the glycosylation abnormalities as measured by $\left[{ }^{3} \mathrm{H}\right]$ mannose labeling be explained simply by changes in the size of the precursor pools or in the specific activities of labeled products? We think this is unlikely since $\left[{ }^{3} \mathrm{H}\right]$ mannose, as a tracer, makes only a small quantitative contribution to oligosaccharide synthesis, and this would not explain the presence of smaller size oligosaccharides in CDGS cells.

Since all of the ${ }^{3} \mathrm{H}$-labeled intermediates except dol-P-Man decreased in the same proportion and were similar to decreases in LLO and protein-linked oligosaccharides, it appears that CDGS cells metabolize mannose normally. Because glucose could not correct both defects, it is tempting to speculate that CDGS cells may be defective in generating mannose from both exogenous and endogenous sources (Fig. 2). The defect in type I CDGS has been mapped to a region on chromosome 16p (56), but it is not clear how a single mutation can account for underutilization of both endogenous and exogenous sources of mannose. Regardless of the source of mannose for glycoprotein synthesis, it is clear that mannose can correct the defects in CDGS fibroblasts. This leads to the intriguing possibility that patients may benefit from an ongoing dietary supplement of mannose or mannose-containing foods. Although very few studies have been done on mannose metabolism in mammals, in moderate doses, mannose should be nontoxic (57). More basic physiological analysis will be required before we can assess the potential benefits of mannose for CDGS patients. 
Note added in proof: A recent report (van Shaftingen, E., and J. Jaeken, 1996. FEBS Lett. 377:318-320) showed that four Type I CDGS patients were $\sim 95 \%$ deficient in phosphomannomutase. The authors concluded that this deficiency is probably the major cause of the disorder. However, their results do not explain how mannose corrects the altered glycosylation in the patients we studied. It remains to be seen whether there are other causes of Type I CDGS.

\section{Acknowledgments}

The authors thank Dr. Ajit Varki for helpful discussions during this work, Dr. Neil Buist for providing CDGS and control cell lines, Dr. James Etchison for help in HPLC analysis, and Drs. Donna M. Krasnewich and Gordon D. Holt for sharing their results before publication. We also thank Felicia Fong for technical assistance and Susan Greaney for secretarial assistance.

This work was supported by a grant from the National Institute of General Medical Sciences (R01 49096).

\section{References}

1. Jaeken, J., H. Carchon, and H. Stibler. 1993. The carbohydrate-deficient glycoprotein syndromes: pre-Golgi and Golgi disorders. Glycobiology. 3:423428.

2. Jaeken, J., H. Stibler, and B. Hagberg. 1991. The carbohydrate-deficient glycoprotein syndrome: a new inherited multisystemic disease with severe nervous system involvement. Acta. Paediatr. Scand. Suppl. 375:1-71.

3. Jaeken, J., E. Eggermont, and H. Stibler. 1987. An apparent homozygous $\mathrm{X}$-linked disorder with carbohydrate-deficient serum glycoproteins. Lancet. 3: 1398.

4. Jaeken, J., H.G. Van Eijk, V. Van der Heul, L. Corbeel, R. Eeckels, and E. Eggermont. 1984. Sialic acid-deficient serum and cerebrospinal fluid transferrin in a newly recognized genetic syndrome. Clin. Chim. Acta. 144:245-247.

5. Jaeken, J., H. Schachter, H. Carchon, P. De Cock, B. Coddeville, and G. Spik. 1994. Carbohydrate deficient glycoprotein syndrome type II: a deficiency in Golgi localized $\mathrm{N}$-acetyl-glucosaminyltransferase II. Arch. Dis. Child. 71: 123-127.

6. Kornfeld, R., and S. Kornfeld. 1985. Assembly of asparagine-linked oligosaccharides. Annu. Rev. Biochem. 54:631-664.

7. Wada, Y., A. Nishikawa, N. Okamoto, K. Inui, H. Tsukamoto, S. Okada, and N. Taniguchi. 1992. Structure of serum transferrin in carbohydrate-deficient glycoprotein syndrome. Biochem. Biophys. Res. Commun. 189:832-836.

8. Yamashita, K., H. Ideo, T. Ohkura, K. Fukushima, I. Yuasa, K. Ohno, and K. Takeshita. 1993. Sugar chains of serum transferrin from patients with carbohydrate deficient glycoprotein syndrome. J. Biol. Chem. 268:5783-5789.

9. Yamashita, K., T. Ohkura, H. Ideo, K. Ohno, and M. Kanai. 1993. Electrospray ionization-mass spectrometric analysis of serum transferrin isoforms in patients with carbohydrate-deficient glycoprotein syndrome. J. Biochem. (Tokyo). 114:766-769.

10. Wada, Y., J. Gu, N. Okamoto, and K. Inui. 1994. Diagnosis of carbohydrate-deficient glycoprotein syndrome by matrix-assisted laser desorption timeof-flight mass spectrometry. Biol. Mass Spectrom. 23:108-109.

11. Yasugi, E., M. Nakasuji, T. Dohi, and M. Oshima. 1994. Major defect of carbohydrate-deficient-glycoprotein syndrome is not found in the synthesis of dolichyl phosphate or $N$-acetylglucosaminyl-pyrophosphoryl-dolichol. Biochem. Biophys. Res. Commun. 200:816-820.

12. Knauer, R., L. Lehle, F. Hanefeld, and K. von Figura. 1994. Normal $\mathrm{N}$-oligosaccharyltransferase activity in fibroblasts from patients with carbohydrate-deficient glycoprotein syndrome. J. Inherited Metab. Dis. 17:541-544.

13. Powell, L., K. Panneerselvam, R. Vij, S. Diaz, A.E. Manzi, N. Buist, H.H. Freeze, and A. Varki. 1994. Carbohydrate-deficient glycoprotein syndrome: not an N-linked oligosaccharide processing defect, but an abnormality in lipid-linked oligosaccharide biosynthesis? J. Clin. Invest. 94:1901-1909.

14. Freeze, H.H. 1993. Preparation and analysis of glycoconjugates. In Current Protocols in Molecular Biology. F.M. Ausubel, R. Brent, R.E. Kington, D.D. Moore, J.G. Seidman, J.A. Smith, and K. Struhl, K, editors. Greene Publishing and Wiley-Interscience, New York. 17.13.1-17.13.16.

15. Rosner, M.R., S.C. Hubbard, R.J. Ivatt, and P.W. Robbins. 1982. $\mathrm{N}$-Asparagine-linked oligosaccharides: biosynthesis of the lipid-linked oligosaccharides. Methods Enzymol. 83:399-408.

16. Sampath, D., A. Varki, and H.H. Freeze. 1992. The spectrum of incomplete $N$-linked oligosaccharides synthesized by endothelial cells in the presence of Brefeldin A. J. Biol. Chem. 267:4440-4455.

17. Freeze, H.H., L. Willies, S. Hamilton, and P. Koza-Taylor. 1989. Two mutants of Dictyostelium discoideum that lack a sulfated carbohydrate antigenic determinant synthesize a truncated lipid-linked precursor of $\mathrm{N}$-linked oligosaccharides. J. Biol. Chem. 264:5653-5659.

18. Varki, A. 1991. Radioactive tracer techniques in the sequencing of glycoprotein oligosaccharides. FASEB J. 5:226-235.

19. Seeholzer, S.H. 1993. Phosphoglucose isomerase: a ketol isomerase with aldol C2-epimerase activity. Proc. Natl. Acad. Sci. USA. 90:1237-1241.

20. Roux, L., S. Holojda, G. Sundblad, H.H. Freeze, and A. Varki. 1988. Sulfated $N$-linked oligosaccharides in mammalian cells. J. Biol. Chem. 263: 8879-8889.

21. Panneerselvam, K., and H.H. Freeze. 1995. Enzymes involved in the synthesis of mannose-6-phosphate from glucose are normal in carbohydrate deficient glycoprotein syndrome fibroblasts. Biochem. Biophys. Res. Commun. 208:517-522.

22. Asano, T., Y. Shibasaki, S. Ohno, H. Taira, J.L. Lin, M. Kasuga, Y. Kanazawa, Y. Akanuma, F. Takaku, and Y. Oka. 1989. Rabbit brain glucose transporter responds to insulin when expressed in insulin-sensitive Chinese hamster ovary cells. J. Biol. Chem. 264:3416-3420.

23. Stoll, J., R. Cacan, A. Verbert, and S.S. Krag. 1992. Lec 15 cells transfer glucosylated oligosaccharides to protein. Arch. Biochem. Biophys. 299:225-231.

24. Gershman, H., and P.W. Robbins. 1981. Transitory effects of glucose starvation on the synthesis of dolichol-linked oligosaccharides in mammalian cells. J. Biol. Chem. 256:7774-7780.

25. Turco, S.J. 1980. Modification of oligosaccharide-lipid synthesis and protein glycosylation in glucose-deprived cells. Arch. Biochem. Biophys. 205: 330-339.

26. Baumann, H., and G.P. Jahreis. 1983. Glucose starvation leads in rat hepatoma cells to partially $N$-glycosylated glycoproteins including $\alpha_{1}$-acid glycoproteins. J. Biol. Chem. 258:3942-3949.

27. Stark, N.J., and E.C. Heath. 1979. Glucose-dependent glycosylation of secretory glycoprotein in mouse myeloma cells. Arch. Biochem. Biophys. 192 599-609.

28. Datema, R., and R.T. Schwarz. 1981. Effect of energy depletion on the glycosylation of a viral glycoprotein. J. Biol. Chem. 256:11191-11198.

29. Davidson, S.K., and L.A. Hunt. 1985. Sindbis virus glycoproteins are abnormally glycosylated in Chinese hamster ovary cells deprived of glucose. $J$. Gen. Virol. 66:1457-1468.

30. Spiro, R.G., M.J. Spiro, and V.D. Bhoyroo. 1983. Studies on the regulation of the biosynthesis of glucose-containing oligosaccharide-lipids. J. Biol. Chem. 258:9469-9476.

31. Rearick, J., A. Chapman, and S. Kornfeld. 1981. Glucose starvation alters lipid-linked oligosaccharide biosynthesis in Chinese hamster ovary cells. $J$. Biol. Chem. 256:6255-6261.

32. Turco, S., and J.L. Pickard. 1982. Altered G-protein glycosylation in vesicular stomatitis virus-infected glucose-deprived baby hamster kidney cells. $J$. Biol. Chem. 257:8674-8679.

33. Varki, A. 1994. Metabolic radiolabeling of glycoconjugates. Methods Enzymol. 230:16-31.

34. Villers, C., R. Cacan, A.M. Mir, O. Labiau, and A. Verbert. 1994. Release of oligomannoside-type glycans as a marker of the degradation of newly synthesized glycoproteins. Biochem. J. 298:135-142.

35. Cacan, R., C. Villers, M. Belard, A. Kaiden, S.S. Krag, and A. Verbert. 1992. Different fates of the oligosaccharide moieties of lipid intermediates. Glycobiology. 2:127-136.

36. Cacan, R., R. Cecchelli, and A. Verbert. 1987. Catabolic pathway of oligosaccharide-diphospho-dolichol: study of the fate of the oligosaccharidic moiety in mouse splenocytes. Eur. J. Biochem. 166:469-474.

37. Cacan, R., A. Lepers, M. Belard, and A. Verbert. 1989. Catabolic pathway of oligosaccharide-diphospho-dolichol: subcellular sites of the degradation of the oligomannoside moiety. Eur. J. Biochem. 185:173-179.

38. Anumula, K.R., and R.G. Spiro. 1983. Release of glucose-containing polymannose oligosaccharides during glycoprotein biosynthesis. J. Biol. Chem 258:15274-15282.

39. Spiro, M.J., and R.G. Spiro. 1991. Potential regulation of N-glycosylation precursor through oligosaccharide-lipid hydrolase action and glucosyltransferase-glucosidase shuttle. J. Biol. Chem. 266:5311-5317.

40. Kmiecik, D., V. Herman, C.J.M. Stroop, J.-C. Michalski, A.-M. Mir, O. Labiau, A. Verbert, and R. Cacan. 1995. Catabolism of glycan moieties of lipid intermediates leads to a single Man5GlcNAc oligosaccharide isomer: a study with permeabilized CHO cells. Glycobiology. 5:483-494.

41. Freeze, H.H., R. Yeh, A.L. Miller, and S. Kornfeld. 1983. Structura analysis of the asparagine-linked oligosaccharides from three lysosomal enzymes of Dictyostelium discoideum. Evidence for an unusual acid-stable phosphodiester. J. Biol. Chem. 258:14874-14879.

42. Carruthers, A. 1990. Facilitated diffusion of glucose. Physiol. Rev. 70: $1135-1176$.

43. Gould, G.W., H.M. Thomas, T.J. Jess, and G.I. Bell. 1991. Expression of human glucose transporters in Xenopus oocytes: kinetic characterization and substrate specificities of the erythrocytes, liver, and brain isoforms. Biochemistry. 30:5139-5145.

44. Miyamoto, K., K. Hase, T. Takagi, T. Fujii, Y. Taketani, H. Minami, T. Oka, and Y. Nakabou. 1993. Differential response of intestinal glucose trans- 
porter mRNA transcripts to levels of dietary sugars. Biochem. J. 295:211-215.

45. Mayor, P., L. Maianu, and W.T. Garvey. 1992. Glucose and insulin chronically regulate insulin action via different mechanisms in $\mathrm{BC}_{3} \mathrm{H} 1$ myocytes. Diabetes. 41:274-285.

46. Krasnewich, D.M., G.D. Holt, M. Brantly, F. Skovby, J. Redwine, and W.A. Gahl. 1995. Abnormal synthesis of dolichol-linked oligosaccharides in carbohydrate-deficient glycoprotein syndrome. Glycobiology. 5:503-510.

47. Chapman, A., K. Fujimoto, and S. Kornfeld. 1980. The primary glycosylation defect in class $\mathrm{E}$ Thy-1-negative mutant mouse lymphoma cells is an ability to synthesize dolichol-P-mannose. J. Biol. Chem. 255:4441-4446.

48. Tachibana, H., and H. Murakami. 1994. Structure and role of oligosaccharide on antibody light chains and their modification with glycosylationbased cytotechnology. Trends Glycosci. \& Glycotechnol. 6:465-475.

49. Goochee, C.F. 1992. Bioprocess factors affecting glycoprotein oligosaccharide structure. Dev. Biol. Stand. 76:95-104.

50. Goochee, C.F., and T. Monica. 1990. Environmental effects on protein glycosylation. Bio/Technology (NY). 8:421-427.

51. Tachibana, H., K. Taniguchi, Y. Ushio, K. Teruya, K. Osada, and H. Murakami. 1994. Changes of monosaccharide availability of human hybridoma lead to alteration of biological properties of human monoclonal antibody. Cytotechnology. 16:151-157.

52. Soyama, K. 1984. Enzymatic determination of D-mannose in serum. Clin. Chem. 30:293-294.

53. Daniel, P.F., B. Winchester, and C.D. Warren. 1994. Mammalian a-mannosidases-multiple forms but a common purpose? Glycobiology. 4:551-566.

54. Payton, M.A., M. Rheinnecker, L.S. Klig, M. DeTiani, and E. Bowden. 1991. A novel saccharomyces cerevisiae secretory mutant possesses a thermolabile phosphomannose isomerase. J. Bacteriol. 173:2006-2010.

55. Asano, T., H. Katagiri, K. Takata, J.L. Lin, H. Ishihara, K. Inukai, K. Tsukua, M. Kikuchi, H. Hirano, and Y. Yazaki. 1991. The role of N-glycosylation of GLUT1 for glucose transport activity. J. Biol. Chem. 266:24632-24636.

56. Martinsson, T., C. Bjursell, H. Stibler, B. Kristiansson, F. Skovby, J. Jaeken, G. Blennow, P. Stromme, F. Hanefeld, and J. Wahlstrom. 1994. Linkage of a locus for carbohydrate-deficient glycoprotein syndrome type I (CDG 1) to chromosome $16 \mathrm{p}$, and linkage disequilibrium to microsatellite marker D16S406. Hum. Mol. Genet. 3:2037-2042.

57. Wood, F.C., and G.F. Cahill. 1963. Mannose utilization in man. J. Clin. Invest. 42:1300-1312. 